\title{
El Hábeas Data en Bolivia
}

\section{Benjamín Miguel Harb}

Si bien el Hábeas Data no está contemplado expresamente en la Constitución o en otras leyes secundarias, creemos que en Bolivia se puede aplicar recurriendo tanto a la Ley Fundamental, al Código Civil y al Código Penal.

La Constitución consagra los derechos, deberes fundamentales y las garantías. A continuación veremos estos derechos:

a) la prohibición de declarar contra sí mismo y contra sus parientes hasta el cuarto grado consanguíneo y segundo afín, para no violentar la conciencia y los lazos familiares;

b) para preservar la intimidad se declara que la correspondencia y los papeles privados son inviolables, sólo pueden ser incautados por orden de autoridad competente, que es el Juez. De igual modo se garantiza la privacidad de las conversaciones y comunicaciones.

c) el domicilio se considera sagrado e inviolable, la persona extraña solo puede ingresar en él con autorización de quien mora o con orden del Juez competente salvo que en él se esté cometiendo delito infraganti;

d) los derechos y garantías consagrados por la Constitución en el estado de sitio, que es de excepción, no quedan en suspenso de hecho y en general, aunque la autoridad fundadamente podrá hacerlo contra los sindicados de alterar el orden público;

e) para garantizar la libertad de conciencia y el derecho a escoger la educación que se quiere la Constitución garantiza la libertad de enseñanza religiosa y la libertad de enseñanza en general; 
f) se declara y garantiza la igualdad de hijos sin distinción de origen como el ejercicio de los derechos nacidos de esta igualdad;

g) se garantiza el secreto al voto como un derecho político personalísimo.

\section{El Código Civil}

Por su parte el Código Civil en lo que se refiere a los derechos personalísimos y de la intimidad establece:

a) el derecho al nombre que comprende el nombre individual, el apellido paterno y materno y se admite su cambio o rectificación siguiendo el trámite prescrito por ley;

Asimismo el hijo tiene derecho a llevar el peligro de su progenitor.

Se garantiza que la persona a quien se discuta el nombre que lleva o sufra algún perjuicio por el uso indebido de ese nombre que haga otra persona puede judicialmente pedir el reconocimiento de su derecho o la cesación de su uso lesivo;

b) toda persona puede negarse y rehusar someterse a un examen médico o someterse a un tratamiento médico quirúrgico, a menos que expresamente la ley le obligue o un reglamento administrativo por la naturaleza de su actividad;

c) se garantiza el derecho a la imagen, cuando sin autorización y consentimiento se exhibe o expone la imagen de una persona, el interesado, su cónyuge o descendiente o ascendiente puede pedir que el juez haga cesar el hecho lesivo;

d) se declara que toda persona tiene derecho a que sea respetado su buen nombre;

e) se garantiza el derecho a la intimidad, nadie puede perturbar la vida íntima de las personas;

f) se declara que los derechos de la personalidad son inherentes al ser humano, están fuera del comercio.

Todos estos derechos que proclama el Código Civil son inviolables, su desconocimiento confiere al damnificado la facultad de demandar penalmente la indemnización por el daño sufrido.

A su vez, el Código Penal tipifica como delitos estas violaciones:

a) los atentados contra la libertad de enseñanza;

b) el allanamiento de domicilio;

c) la violación de los papeles privados. 


\section{Recurso de Amparo}

La demanda de Hábeas Corpus es para defender la libertad de las personas cuando se creyere indebida e ilegalmente perseguidas, detenidas, procesadas o presas. Para otras violaciones de los derechos, se tiene el Recurso de Amparo declarado por la Constitución en el artículo $19^{\circ}$, al tenor siguiente:

"I. Fuera del recurso de hábeas corpus a que se refiere el artículo $18^{\circ}$, se establece el recurso de amparo contra los actos ilegales o las omisiones indebidas de los funcionarios o particulares que restrinjan, supriman o amenacen suprimir o restringir los derechos y garantías de la persona reconocidos por esta Constitución y las leyes.

II. El recurso de amparo se interpondrá por la persona que se creyere agraviada o por otra a su nombre con poder suficiente salvo lo dispuesto en el artículo $129^{\circ}$ de esta Constitución (referente a las facultades del Defensor del Pueblo para este recurso), ante las Cortes Superiores en las capitales de Departamento o ante los jueces de Partido en las Provincias, tramitándoselo en forma sumarísima. El Ministerio Público podrá también interponer de oficio este recurso cuando no lo hiciere o no pudiere hacerlo la persona afectada.

III. La autoridad o la persona demandada será citada en la forma prevista por el artículo anterior (Hábeas Corpus) a objeto de que preste información y presente en su caso, los actuados concernientes al hecho denunciado en el plazo máximo de cuarenta y ocho horas.

IV. La resolución final se pronunciará en audiencia pública inmediatamente de recibida la información del denunciado y, a falta de ella lo hará sobre la base de la prueba que ofrezca el recurrente.

La autoridad judicial examinará la competencia del funcionario o los actos del particular y encontrando cierta y efectiva la denuncia, concederá el amparo solicitado siempre que no hubiere otro medio recurso legal para la protección inmediata de los derechos y garantías restringidos elevando de oficio su resolución ante el Tribunal Constitucional para su revisión en el plazo de veinticuatro horas. 
V. Las determinaciones previstas de la autoridad judicial y la decisión final que conceda el amparo serán ejecutadas inmediatamente y sin observancia, aplicándose, en caso de resistencia, lo dispuesto en el Hábeas Corpus (delito contra las garantías constitucionales)".

De acuerdo al concepto constitucional, el Recurso de Amparo es una garantía constitucional que protege los derechos fundamentales que en la primera parte de este trabajo hemos visto, excepto la libertad que es objeto del Hábeas Corpus. Es un recurso amplio cuando los derechos mencionados son violados.

El Recurso de Amparo protege de modo general todos los derechos fundamentales que no están amparados por otras leyes. Pero aun en este caso, habiendo otra vía para la protección, si esta "no es inmediata" en reponer los derechos y garantías restringidos, suprimidos o amenazados procedería el Hábeas Data, pudiendo en la vía ordinaria seguirse un proceso por separado e independiente de este recurso. La vía ordinaria que señala la ley para reparar las violaciones de los derechos personalísimos e íntimos, de ninguna manera puede ser inmediata puesto que está sometida a todo un procesamiento, por ello entendiéndose bien los términos constitucionales: "contra actos ilegales u omisiones que restrinjan, supriman o amenacen restringir o suprimir"; y "siempre que no hubiere otro medio legal para la protección inmediata de los derechos y garantías restringidos, suprimidos o amenazados", nos permite afirmar que el Recurso de Amparo en Bolivia puede aplicarse con Hábeas Data. 